\title{
PERFORMANCE OF EQUITY MUTUAL FUNDS IN INDIA: AN ANALYSIS OF SELECT ASSET MANAGEMENT COMPANIES
}

\author{
L V Kamala Devi \\ Scholar Rayalaseema University, Assistant Professor, Bhavan's Vivekananda College, \\ Sainikpuri, Hyderabad, Telangana, India \\ Prashanta Athma \\ Professor, Chairperson, Board of Studies, Department of Commerce, Osmania University, \\ Hyderabad, Telangana, India
}

\begin{abstract}
Financial System of the economy bridges a gap between people who have excess funds and the ones with deficit of Funds. Mutual Fund business has become a worthy option for Investment in Indian Financial Markets where majority of middle Indian families are those who want to get supreme return with a minimum risk and tax savings. The main objective of 'selectivity on the return of select Mutual Fund Schemes and observes that fund managers diversification did not fetch much returns on the schemes selected in the study.
\end{abstract}

Key words: Rolling Returns, Beta, Asset under Management, Diversification and Selectivity.

Cite this Article: L V Kamala Devi and Prashanta Athma, Performance of Equity Mutual Funds in India: An Analysis of Select Asset Management Companies, International Journal of Management, 11(12), 2020, pp. 1853-1863. http://www.iaeme.com/IJM/issues.asp?JType=IJM\&VType=11\&IType=12

\section{INTRODUCTION}

Economy is highly influenced by the Financial System of that country. It basically comprises of two groups, ones with excess funds and ones with deficit of Funds. Financial System of the economy bridges a gap between these two groups by providing money to people who want from those who have. Mutual Fund industry has become a worthy option for Investment in our countries Financial Markets where majority of middle class families are those who want to get maximum return with a minimum risk and tax savings. The heart of a Mutual Fund lies in pooling money from various segments of stakeholders by issuing units, build a varied portfolio of shares, bonds and other investment devices, and finance the same in the Investment market. The main aim of Mutual Funds is to provide decent returns on the investment by lessening risk 
related to Stock Market Investments. However Mutual Funds are subject to risk and therefore the expected returns are based on the risk attached to the investments.

The main concern of Mutual Fund Unit Holders is the performance of the Units purchased by them. A Majority of the investors in Mutual Fund invest through Fund Managers in order to benefit from their experience and expertise. The present study aims to address two major queries of a Mutual Fund Unit Holder.

- Are Equity Mutual Funds appreciated by earning excess returns compared to benchmark returns?

- Whether equity Mutual Funds get the benefits of diversification, and securities selectivity.

To answer the above queries the following objectives are framed.

\section{OBJECTIVES}

The Objectives of the study are to:

- Evaluate the Risk and Return of the select Asset Management Companies (AMCs).

- Compare the Return of the select AMCs with the benchmark return.

- Examine the impact of diversity and selectivity on the return of select Equity Schemes.

\section{METHODOLOGY}

\subsection{Period of the Study}

A seventeen year time period is taken for the study from 2003 to 2019 for the purpose of evaluation of performance of Mutual Funds. The year 2003 is taken as starting point, as earlier to this year; UTI was governed by the Government of India. In 2003, UTI was bifurcated into UTI Asset Management Company and Axis Bank.

\subsection{Selection of AMCs}

Top 10 Asset Management Companies (AMC) on the basis of Average Assets Under Management (AAUM) which had equity schemes from 2003 onwards were taken into consideration. The 10 Average Assets Under Management (AAUM) for the study purpose are Aditya Birla Sun Life Mutual Fund, DSP Mutual Fund, Franklin India Mutual Fund, HDFC Mutual Fund, ICICI Prudential Mutual Fund, Kotak Mutual Fund, Nippon India Mutual, Tata Mutual Fund, SBI Mutual Fund and UTI Mutual Fund accordingly. Out of the 44 AMCs mentioned in Annexure 1 all those AMCs which either did not have Equity Schemes or were not yet established in 2003 are ignored as the period of study is from 1.4.2003.

\section{- Selection of Schemes}

All the select Companies offering equity schemes uniformly for all the seventeen years of the study period (2003-2019) are considered to be the base for selecting the schemes. Accordingly 37 Equity Schemes (shown in Table 1) form the basis for the study.

\section{- Parameters}

The aspects/variables for evaluating performance are Risk, Return and Reward to variability.

\subsection{Tools for Analysis}

Data are analyzed with the help of Statistical tools like Averages, Percentages, Standard Deviation and Beta. 
Financial Performance evaluation tools like Sharpe Ratio, Treynor Ratio, Jensen Performance Index and Fama's Net Selectivity are employed for the analysis of data.

Performance of Select Equity Schemes

The performance of Select Schemes is evaluated in terms of Risk and Return. The returns are taken on a Rolling basis in order to eliminate the bias and give more accuracy. The Risk is measured in terms of Standard Deviation as it gives the total Risk.

The Returns are calculated as follows

Rp: Net Asset Value (t)-Net Asset Value (t-1 )

Net Asset Value t-1
Where
Rp Is Portfolio Return
$\mathbf{t}$ is the Time Period

- Return Analysis: The Analysis of Return is done for all the 37 Equity schemes of Select AMC's with the help of Rolling Return which are indications of Average Return of Number of data points removing the bias related to the returns which are calculated at one particular point. The more the data points the more the accuracy.

\begin{tabular}{|c|c|c|c|c|c|}
\hline S.No. & Scheme Name & Rolling Return & Rank & Standard Deviation & Rank \\
\hline & I) ADITYA BIRLA SUNLIFE MUTUAL FUND & & & & \\
\hline 1 & Aditya Birla SL Equity Advantage Fund(G) & 0.20 & 30 & 17.27 & 32 \\
\hline 2 & Aditya Birla SL Frontline Equity Fund(G) & 0.22 & 21 & 15.27 & 14 \\
\hline 3 & Aditya Birla SL Midcap Fund(G) & 0.25 & 7 & 17.93 & 34 \\
\hline \multirow[t]{2}{*}{4} & Aditya Birla SL MNC Fund(G) & $\mathbf{0 . 2 4}$ & 12 & 14.18 & 4 \\
\hline & II) DSP Mutual Fund & & & & \\
\hline 5 & DSP Equity Opportunities Fund(G) & $\mathbf{0 . 2 3}$ & 16 & 16.98 & 30 \\
\hline \multirow[t]{3}{*}{6} & DSP Top 100 Equity Fund(G) & 0.21 & 28 & 13.57 & 3 \\
\hline & III) Franklin India Mutual Fund & & & & \\
\hline & Franklin India Bluechip Fund(G) & 0.20 & 31 & 14.54 & 8 \\
\hline 8 & Franklin India Equity Fund(G) & $\mathbf{0 . 2 2}$ & 18 & 14.62 & 9 \\
\hline 9 & Franklin India Opportunities Fund(G) & 0.20 & 29 & 16.39 & 24 \\
\hline 10 & Franklin India Prima Fund(G) & $\mathbf{0 . 2 5}$ & 5 & 18.52 & 36 \\
\hline 11 & Franklin India Taxshield(G) & 0.22 & 19 & 14.51 & 7 \\
\hline \multirow[t]{2}{*}{12} & Franklin India Technology Fund(G) & 0.20 & 32 & 16.09 & 20 \\
\hline & IV) HDFC Mutual Fund & & & & \\
\hline 13 & HDFC Capital Builder Value Fund(G) & 0.24 & 13 & 16.75 & 28 \\
\hline 14 & HDFC Equity Fund(G) & $\mathbf{0 . 2 4}$ & 11 & 16.34 & 22 \\
\hline 15 & HDFC Growth Opp Fund(G) & 0.17 & 36 & 16.29 & 21 \\
\hline 16 & HDFC TaxSaver(G) & $\mathbf{0 . 2 4}$ & 10 & 15.91 & 18 \\
\hline \multirow[t]{2}{*}{17} & HDFC Top 100 Fund(G) & $\mathbf{0 . 2 3}$ & 15 & 15.03 & 13 \\
\hline & V) ICICI Prudential Mutual Fund & & & & \\
\hline 18 & ICICI Pru FMCG Fund(G) & $\mathbf{0 . 2 5}$ & 6 & 14.94 & 11 \\
\hline 19 & $\mathrm{ICICI}$ Pru Large \& Mid Cap Fund(G) & 0.19 & 33 & 14.22 & 5 \\
\hline 20 & ICICI Pru LT Equity Fund (Tax Saving)(G) & $\mathbf{0 . 2 5}$ & 8 & 15.98 & 19 \\
\hline 21 & ICICI Pru Multicap Fund(G) & 0.21 & 24 & 16.38 & 23 \\
\hline \multirow[t]{2}{*}{22} & $\mathrm{ICICI}$ Pru Savings Fund(G) & 0.08 & 37 & 1.75 & 1 \\
\hline & VI) KOTAK MUTUAL FUND & & & & \\
\hline \multirow[t]{2}{*}{23} & Kotak Bluechip Fund(G) & 0.21 & 25 & 14.80 & 10 \\
\hline & VII) NIPPON INDIA MUTUAL FUND & & & & \\
\hline 24 & Nippon India Growth Fund(G) & 0.26 & 3 & 17.20 & 31 \\
\hline \multirow[t]{2}{*}{25} & Nippon India Vision Fund(G) & 0.21 & 27 & 16.46 & 25 \\
\hline & VIII) TATA MUTUAL FUND & & & & \\
\hline 26 & Tata Ethical Fund(G) & 0.24 & 9 & 16.47 & 26 \\
\hline 27 & Tata Index Fund-Sensex Plan(G) & 0.21 & 26 & 14.44 & 6 \\
\hline 28 & Tata Large \& Mid Cap Fund(G) & 0.25 & 4 & 16.57 & 27 \\
\hline \multirow[t]{2}{*}{29} & Tata Large Cap Fund(G) & $\mathbf{0 . 2 7}$ & 2 & 16.88 & 29 \\
\hline & IX) SBI MUTUAL FUND & & & & \\
\hline 30 & SBI Healthcare Opp Fund(G) & 0.21 & 22 & 15.74 & 16 \\
\hline 31 & SBI Large \& Midcap Fund(G) & 0.29 & 1 & 18.86 & 37 \\
\hline 32 & SBI Magnum Equity ESG Fund(G) & 0.22 & 17 & 18.08 & 35 \\
\hline 33 & SBI Magnum Global Fund(G) & 0.17 & 35 & 15.87 & 17 \\
\hline 34 & SBI Magnum TaxGain'93(G) & $\mathbf{0 . 2 3}$ & 14 & 17.50 & 33 \\
\hline \multirow[t]{2}{*}{35} & SBI Contra Fund(G) & 0.21 & 23 & 15.00 & 12 \\
\hline & X) UTI MUTUAL FUND & & & & \\
\hline 36 & UTI MNC Fund(G) & 0.22 & 20 & 13.27 & 2 \\
\hline \multirow[t]{8}{*}{37} & UTI Nifty Index Fund(G) & 0.17 & 34 & 15.38 & 15 \\
\hline & Average & 0.22 & & 15.57 & \\
\hline & Maximm & 0.29 & & 18.86 & \\
\hline & Minimum & 0.08 & & 1.75 & \\
\hline & $\%$ Above Average & 48.65 & & & \\
\hline & No above average & 18 & & & \\
\hline & Benchmark return/Standard Deviation & 0.17 & & 24.91 & \\
\hline & Above benchmark return & 36 & & & \\
\hline
\end{tabular}


Rolling Return is applied on the Portfolios and on Benchmark Indices. In this study, 17 years Rolling Returns are calculated from $1^{\text {st }}$ April 2003 to $31^{\text {st }}$ March 2020. Average Annual Rolling returns are calculated e.g.; From $1^{\text {st }}$ April 2003 to $1^{\text {st }}$ April 2004, $2^{\text {nd }}$ April 2003 to $2^{\text {nd }}$ April 2004, $3^{\text {rd }}$ April 2003 to $3^{\text {rd }}$ April 2004, $4^{\text {th }}$ April 2003 to $4^{\text {th }}$ April 2004 and so on till $31^{\text {st }}$ March 2019 to $31^{\text {st }}$ March 2020.This gives a total of 6209 Observations in a period of 17 Years. The Risk \& Return for the equity Schemes of Select AMC's is presented in Table1.Table 1 is being calculated on rolling returns for a period of 17 years with Nifty 50 as the Benchmark Index and Risk-Free Asset is 7\%.

\section{Rolling Returns}

From the table, it is evident that all 0the 37 Schemes have Positive Rolling Returns and 35 Schemes out of 37 Schemes have Returns higher than the Benchmark Returns and also that $49 \%$ of the Schemes i.e., approx. half of the schemes have above average Rolling Returns. SBI Large and Midcap Fund earn the highest return of $29.27 \%$ over a period of 17 years followed by Tata Large Cap Fund with $27.02 \%$ and Nippon India Growth Fund at 26.27\%. Out of 37 Schemes only 2 Schemes i.e., HDFC Growth Opportunities Fund and ICICI Prudential Saving Fund Returns have return less than the Benchmark Returns.

\section{- Risk Analysis:}

The Risk is Analyzed with the help of Standard Deviation for the select schemes as shown in Table 1

$$
\sigma=\sqrt{\frac{\sum(x-\bar{x})^{2}}{N}}
$$

Where, $\mathrm{x}=$ portfolio return; $\overline{\mathrm{x}}=$ mean portfolio return; $\mathrm{N}=$ Time Period.

Investors are generally Risk averse as they are conservative and they don't mind getting a lower return. Lower the Standard deviation, lower the returns. The scheme with lowest rank is given $1^{\text {st }}$ rank and the scheme with high risk is given last rank. Only those investors who are risk takers would select the scheme with higher risk in order to reap better returns. Out of the 37 Schemes we find that none of the schemes has risk higher than that of the Benchmark. Highest Standard deviation is with SBI Large and Midcap Fund and we find that it also has the highest Rolling return. This shows that the schemes which has taken risk also could earn the highest.

Performance Evaluation of the schemes is analysed with the help of Performance

Evaluation Models namely Sharpe Ratio, Treynor Ratio and Jenson's Alpha and the same is reflected in Table 2 . 


\begin{tabular}{|c|c|c|c|c|c|c|c|}
\hline \multicolumn{8}{|c|}{ Table 2 Performance Evaluation } \\
\hline S.No & Scheme Name & Sharpe & Ranking & Treynor & Ranking & Jensen's & Ranking \\
\hline & I) ADITYA BIRLA SUNLIFE MUTUAL FUND & & & & & & \\
\hline 1 & Aditya Birla SL Equity Advantage Fund(G) & 0.46 & 31 & 13.32 & $\overline{32}$ & 2.02 & 31 \\
\hline 2 & Aditya Birla SL Frontline Equity Fund(G) & 0.55 & 7 & 15.20 & 15 & 3.67 & 20 \\
\hline 3 & Aditya Birla SL Midcap Fund(G) & 0.50 & 20 & 14.86 & 19 & 4.15 & 13 \\
\hline \multirow[t]{2}{*}{4} & Aditya Birla SL MNC Fund(G) & 0.57 & 3 & 18.75 & 3 & $\mathbf{6 . 7 2}$ & 4 \\
\hline & II) DSP Mutual Fund & & & & & & \\
\hline 5 & DSP Equity Opportunities Fund(G) & 0.53 & 12 & 14.92 & 17 & 3.90 & 16 \\
\hline \multirow[t]{3}{*}{6} & DSP Top 100 Equity Fund(G) & 0.51 & 18 & 13.73 & 29 & 2.86 & 26 \\
\hline & III) Franklin India Mutual Fund & & & & & & \\
\hline & Franklin India Bluechip Fund(G) & 0.48 & 27 & 13.80 & 27 & 2.48 & 30 \\
\hline 8 & Franklin India Equity Fund(G) & 0.55 & 8 & 15.55 & 13 & 4.18 & 12 \\
\hline 9 & Franklin India Opportunities Fund(G) & 0.46 & 30 & 12.96 & 33 & 1.48 & 33 \\
\hline 10 & Franklin India Prima Fund(G) & 0.51 & 17 & 15.67 & 9 & 5.25 & 7 \\
\hline 11 & Franklin India Taxshield(G) & 0.54 & 9 & 15.57 & 12 & 4.07 & 14 \\
\hline \multirow[t]{2}{*}{12} & Franklin India Technology Fund(G) & 0.42 & 35 & 15.64 & 10 & 3.54 & 21 \\
\hline & IV) HDFC Mutual Fund & & & & & & \\
\hline 13 & HDFC Capital Builder Value Fund(G) & 0.53 & 11 & 15.82 & 7 & 4.82 & 9 \\
\hline 14 & HDFC Equity Fund(G) & 0.52 & 14 & 14.62 & 20 & 3.77 & 19 \\
\hline 15 & HDFC Growth Opp Fund(G) & 0.39 & 36 & 10.99 & 35 & -0.76 & 37 \\
\hline 16 & HDFC TaxSaver(G) & 0.50 & 22 & 14.99 & 16 & 4.21 & 11 \\
\hline \multirow{2}{*}{17} & HDFC Top 100 Fund(G) & 0.53 & 10 & 14.92 & 18 & 3.87 & 17 \\
\hline & V) ICICI Prudential Mutual Fund & & & & & & \\
\hline 18 & ICICI Pru FMCG Fund(G) & 0.64 & 1 & 22.90 & 1 & 9.19 & 1 \\
\hline 19 & ICICI Pru Large \& Mid Cap Fund(G) & 0.49 & 24 & 13.58 & 31 & 1.90 & 32 \\
\hline 20 & ICICI Pru LT Equity Fund (Tax Saving)(G) & 0.50 & 19 & 15.43 & 14 & 4.73 & 10 \\
\hline 21 & $\mathrm{ICICI}$ Pru Multicap Fund(G) & $\mathbf{0 . 5 0}$ & 21 & 13.94 & 26 & 2.58 & 28 \\
\hline \multirow[t]{2}{*}{22} & $\mathrm{ICICI}$ Pru Savings Fund(G) & 0.30 & 37 & 1.65 & 37 & 0.68 & 34 \\
\hline & VI) KOTAK MUTUAL FUND & & & & & & \\
\hline \multirow[t]{2}{*}{23} & Kotak Bluechip Fund(G) & 0.51 & 16 & 14.14 & 25 & 2.97 & 25 \\
\hline & VII) NIPPON INDIA MUTUAL FUND & & & & & & \\
\hline 24 & Nippon India Growth Fund(G) & 0.57 & 4 & 17.46 & 4 & 8.06 & 2 \\
\hline \multirow[t]{2}{*}{25} & Nippon India Vision Fund(G) & 0.47 & 29 & 14.17 & 24 & 3.40 & 22 \\
\hline & VIII) TATA MUTUAL FUND & & & & & & \\
\hline 26 & Tata Ethical Fund(G) & 0.49 & 25 & $\mathbf{1 4 . 5 3}$ & 21 & 3.77 & 18 \\
\hline 27 & Tata Index Fund-Sensex Plan(G) & 0.43 & 33 & 15.61 & 11 & 3.90 & 15 \\
\hline 28 & Tata Large \& Mid Cap Fund(G) & 0.56 & 6 & 15.72 & 8 & 5.17 & 8 \\
\hline \multirow[t]{2}{*}{29} & Tata Large Cap Fund(G) & 0.51 & 15 & 16.01 & 6 & $\mathbf{6 . 0 0}$ & 5 \\
\hline & IX) SBI MUTUAL FUND & & & & & & \\
\hline 30 & SBI Healthcare Opp Fund(G) & 0.52 & 13 & 14.17 & 23 & 2.85 & 27 \\
\hline 31 & SBI Large \& Midcap Fund(G) & 0.56 & 5 & 16.73 & 5 & 7.20 & 3 \\
\hline 32 & SBI Magnum Equity ESG Fund(G) & 0.49 & 26 & 13.68 & 30 & 2.51 & 29 \\
\hline 33 & SBI Magnum Global Fund(G) & 0.42 & 34 & 10.96 & 36 & -0.13 & 36 \\
\hline 34 & SBI Magnum TaxGain'93(G) & 0.48 & 28 & 13.77 & 28 & 2.99 & 24 \\
\hline \multirow[t]{2}{*}{35} & SBI Contra Fund(G) & 0.49 & 23 & 14.26 & 22 & 3.01 & 23 \\
\hline & X) UTI MUTUAL FUND & & & & & & \\
\hline 36 & UTI MNC Fund(G) & 0.57 & 2 & 18.77 & 2 & 5.95 & 6 \\
\hline \multirow[t]{6}{*}{37} & UTI Nifty Index Fund(G) & 0.44 & 32 & 11.90 & 34 & 0.28 & 35 \\
\hline & Average & 0.50 & & 14.61 & & 3.71 & \\
\hline & Maximm & 0.64 & & 22.90 & & 9.19 & \\
\hline & Minimum & 0.30 & & 1.65 & & -0.76 & \\
\hline & $\%$ Above Average & 59.46 & & 56.76 & & 51.35 & \\
\hline & No above average & 22 & & 21 & & 19 & \\
\hline
\end{tabular}


Sharpe Ratio: Sharpe Ratio was developed by William Sharpe in the year 1965 to assess the Risk Adjusted Portfolio performance. In this ratio excess returns over the Risk-free Rate is related to the Portfolios Full Risk i.e. Standard Deviation. It means returns of Portfolio in excess of Risk-free Rate is divided with Standard Deviation of the Portfolio Returns. Higher the ratio higher the returns.

Sharpe Ratio $=(R p-R f) / \sigma p$

Where: $\mathrm{Rp}=$ Portfolio Return; $\mathrm{Rf}=$ RiskFree Rate; $\sigma p=$ Standard Deviation

Risk free Rate: 10 Years Government Security is taken as Risk Free Rate for Equity Mutual Funds.

It indicates the additional return over Risk Free Rate per unit of risk involved i.e., per unit of Standard Deviation. The table indicates that nearly $60 \%$ of the schemes selected are above the Average Sharpe Ratio of 0.50. ICICI Pru FMCG Fund earns the highest return of 0.64 compared to total risk followed by UTI MNC Fund and Aditya Birla Sunlife MNC Fund 0.5717 and 0.57 Sharpe Ratio. All the Schemes have Positive Sharpe Ratio i.e are earning enough of Returns over Risk Free rate per unit of Total Risk.

- Treynor Ratio: is a performance metric for determining how much excess return was generated for each unit of systematic risk taken on by a portfolio. Excess return in this sense refers to the return earned above the return that could have been earned in a risk-free investment. Although there is no true risk-free investment, 10 Years Government Securities are taken in this study. Risk in the Treynor ratio refers to systematic risk as measured by a portfolio beta which reflects the tendency of a portfolio return to change in response to changes in return for the overall market.

- Treynor Ratio $=(R p-R$ f $) / \beta$ p

Where: $\mathrm{R} \mathrm{p}=$ Portfolio return; $\mathrm{R} F=$ Risk-free rate; $\beta \mathrm{p}=$ Beta of the portfolio.

Beta ( $\beta$ ): Bets describes how the expected return of a stock or portfolio is correlated to the return of the market as a whole.

For instance, $\beta=+1.0$ represents one percent change in market index returns causes exactly one percent change in the security return. It indicates that the security moves in tandem with the market.

\section{Beta coefficient $(\boldsymbol{\beta})=$ Covariance $(\boldsymbol{R e}, \mathrm{Rm}) /$ Variance $(\boldsymbol{R m})$}

Nifty 50 is taken as the Benchmark Index for evaluating the Portfolio returns. These returns are also calculated on Rolling Return basis.

The average Treynor ratio is $14.61 \%$. It is evident from the information that 21 Schemes out of 37 Schemes have earned returns above Average Treynor Ratio. ICICI FMCG Fund has proved itself to be the best against Systematic Risk with $22.90 \%$ Treynor Ratio followed by UTI MNC Fund and Aditya Birla Sun Life MNC Fund with 18.77 and 18.75 Ratios.

- Jensons Alpha: is a risk-adjusted performance measure that represents the average return on a portfolio or investment, above or below that predicted by the Capital Asset Pricing Model (CAPM), given the portfolio's or investment's beta and the average market return. This metric is also commonly referred to as simply alpha.

Jensen's Alpha $=R_{p}-\left(R+\beta_{p} *\left(R_{m}-R_{F}\right)\right)$

Where: $R_{p}=$ Portfolio Returns; $R_{F}=$ Risk Free Return; $\beta_{p}=$ Beta of the portfolio; $R_{m}=$ Market return 
Jenson's measures talks about the Additional Return a fund should earn with respect to Systematic Risk. The Excess return earned shows its superior performance called as Alpha. A positive Alpha denotes better performance and negative Alpha denotes poor performance of the Fund. It is evident from the table that except 2 Schemes namely HDFC Growth Opportunities Fund and SBI Magnum Global Fund, all schemes have Positive Alpha denoting better performance of the Schemes selected in the study. 19 Schemes out of 37 Schemes have Alpha above the Average Alpha of Schemes selected. The Scheme with the highest Alpha which could also beat the Total Risk and Systematic Risk is ICICI Pru FMCG Fund followed by SBI Large and Midcap Fund and Nippon India Growth Fund. UTI MNC Fund and Aditya Birla Sun Life MNC Fund which earned good returns in Shape and Treynor Ratio could not earn a higher Alpha.

An Investor would go for Mutual Fund to reap the benefit of diversification of Risk effectively managed by AMCs as the investor does not have the specialized knowledge relating to the portfolios. Diversification and selectivity have an impact on the returns and the same are analyzed with the help of Square and Fama's Net Selectivity measure. The impact of diversification and selectivity on the return of select Equity schemes is presented in Table 3

\subsection{Diversification}

$\mathrm{R}$ Squared is a simple way to assess Mutual fund. It is to basically analyse Funds connectivity to a given benchmark. It relates the Portfolio return to Benchmark and states the relation as a percentage. Greater the percentage, higher the Portfolio movement reflected with that of the Benchmark.

\begin{tabular}{|c|c|c|c|c|c|c|c|c|}
\hline & Particulars YEAR 2003-2019 & $\begin{array}{l}\text { R- } \\
\text { Squared }\end{array}$ & $\begin{array}{l}\text { Risk } \\
\text { Free } \\
\text { Rate }\end{array}$ & \begin{tabular}{|c|} 
R1 \\
Impact of \\
Systemat \\
ic Return
\end{tabular} & $\begin{array}{c}\text { R2 Impact } \\
\text { of } \\
\text { imperfect } \\
\text { Diversificat } \\
\text { ion }\end{array}$ & $\begin{array}{c}\text { Rf+R1+R2 } \\
\text { Return from } \\
\text { diversified } \\
\text { risk }\end{array}$ & \begin{tabular}{|c} 
Net \\
superior \\
Return from \\
selectivity
\end{tabular} & Rank \\
\hline & I) ADITYA BIRLA SUNLIFE MUTUAL & & & & & & & \\
\hline 1 & Aditya Birla SL Equity Advantage Fund(G) & $81.64 \%$ & 0.07 & 0.11 & -0.04 & 0.14 & $6.31 \%$ & 33 \\
\hline 2 & Aditya Birla SL Frontline Equity Fund(G) & $94.44 \%$ & 0.07 & 0.10 & -0.04 & 0.13 & $8.54 \%$ & 20 \\
\hline 3 & Aditya Birla SL Midcap Fund(G) & $81.22 \%$ & 0.07 & 0.13 & -0.06 & 0.14 & $10.69 \%$ & 11 \\
\hline \multirow[t]{2}{*}{4} & Aditya Birla SL MNC Fund(G) & $65.69 \%$ & 0.07 & 0.09 & -0.04 & 0.13 & $11.01 \%$ & 7 \\
\hline & II) DSP Mutual Fund & & & & & & & \\
\hline 5 & DSP Equity Opportunities Fund(G) & $88.38 \%$ & 0.07 & 0.12 & -0.05 & 0.14 & $9.05 \%$ & 18 \\
\hline \multirow[t]{2}{*}{6} & DSP Top 100 Equity Fund(G) & $91.56 \%$ & 0.07 & 0.10 & -0.05 & 0.12 & $8.13 \%$ & 24 \\
\hline & III) Franklin India Mutual Fund & & & & & & & \\
\hline 7 & Franklin India Bluechip Fund(G) & $80.55 \%$ & 0.07 & 0.11 & -0.05 & 0.13 & $7.34 \%$ & 28 \\
\hline 8 & Franklin India Equity Fund(G) & $89.39 \%$ & 0.07 & 0.11 & -0.05 & 0.13 & $9.27 \%$ & 16 \\
\hline 9 & Franklin India Opportunities Fund(G) & $89.30 \%$ & 0.07 & 0.11 & -0.05 & 0.13 & $6.83 \%$ & 30 \\
\hline 10 & Franklin India Prima Fund(G) & $74.41 \%$ & 0.07 & 0.13 & -0.06 & 0.14 & $10.88 \%$ & 9 \\
\hline 11 & Franklin India Taxshield(G) & $86.13 \%$ & 0.07 & 0.10 & -0.04 & 0.13 & $8.90 \%$ & 19 \\
\hline \multirow[t]{2}{*}{12} & Franklin India Technology Fund(G) & $47.93 \%$ & 0.07 & 0.08 & -0.02 & 0.13 & $6.65 \%$ & 32 \\
\hline & IV) HDFC Mutual Fund & & & & & & & \\
\hline 13 & HDFC Capital Builder Value Fund(G) & $80.31 \%$ & 0.07 & 0.11 & -0.05 & 0.14 & $9.96 \%$ & 13 \\
\hline 14 & HDFC Equity Fund(G) & $90.33 \%$ & 0.07 & 0.13 & -0.06 & 0.13 & $10.37 \%$ & 12 \\
\hline 15 & HDFC Growth Opp Fund(G) & $85.35 \%$ & 0.07 & 0.10 & -0.04 & 0.13 & $3.16 \%$ & 36 \\
\hline 16 & HDFC TaxSaver(G) & $79.23 \%$ & 0.07 & 0.12 & -0.06 & 0.13 & $10.99 \%$ & 8 \\
\hline \multirow[t]{2}{*}{17} & HDFC Top 100 Fund(G) & $90.68 \%$ & 0.07 & 0.12 & -0.06 & 0.13 & $9.86 \%$ & 14 \\
\hline & V) ICICI Prudential Mutual Fund & & & & & & & \\
\hline 18 & $\mathrm{ICICI}$ Pru FMCG Fund(G) & $55.85 \%$ & 0.07 & 0.08 & -0.02 & 0.13 & $12.16 \%$ & 4 \\
\hline 19 & ICICI Pru Large \& Mid Cap Fund(G) & $92.65 \%$ & 0.07 & 0.10 & -0.04 & 0.13 & $6.66 \%$ & 31 \\
\hline 20 & ICICI Pru LT Equity Fund (Tax Saving)(G) & $76.15 \%$ & 0.07 & 0.12 & -0.06 & 0.13 & $11.45 \%$ & 6 \\
\hline 21 & $\mathrm{ICICI}$ Pru Multicap Fund(G) & $92.12 \%$ & 0.07 & 0.11 & -0.05 & 0.13 & $7.80 \%$ & 27 \\
\hline \multirow[t]{2}{*}{22} & $\mathrm{ICICI}$ Pru Savings Fund $(\mathrm{G})$ & $45.86 \%$ & 0.07 & 0.04 & -0.03 & 0.08 & $-0.11 \%$ & 37 \\
\hline & VI) KOTAK MUTUAL FUND & & & & & & & \\
\hline 23 & Kotak Bluechip Fund(G) & $90.00 \%$ & 0.07 & 0.10 & -0.05 & 0.13 & $8.07 \%$ & 26 \\
\hline
\end{tabular}


$\mathrm{R}$ squared helps in Funds reflection by planning the portfolio diversification, in order to minimize the losses due to risk. For example if $\mathrm{R}^{2}$ is or $30 \%\left(1 / 3^{\text {rd }}\right)$ it says the Fund is low correlated to benchmark and if it is a higher percentage say more than $70 \%\left(2 / 3^{\text {rd }}\right)$ it is said to be highly correlated to the benchmark. R squared is calculated to understand the diversification of the fund and the same is compared with Fama's Net Selectivity.

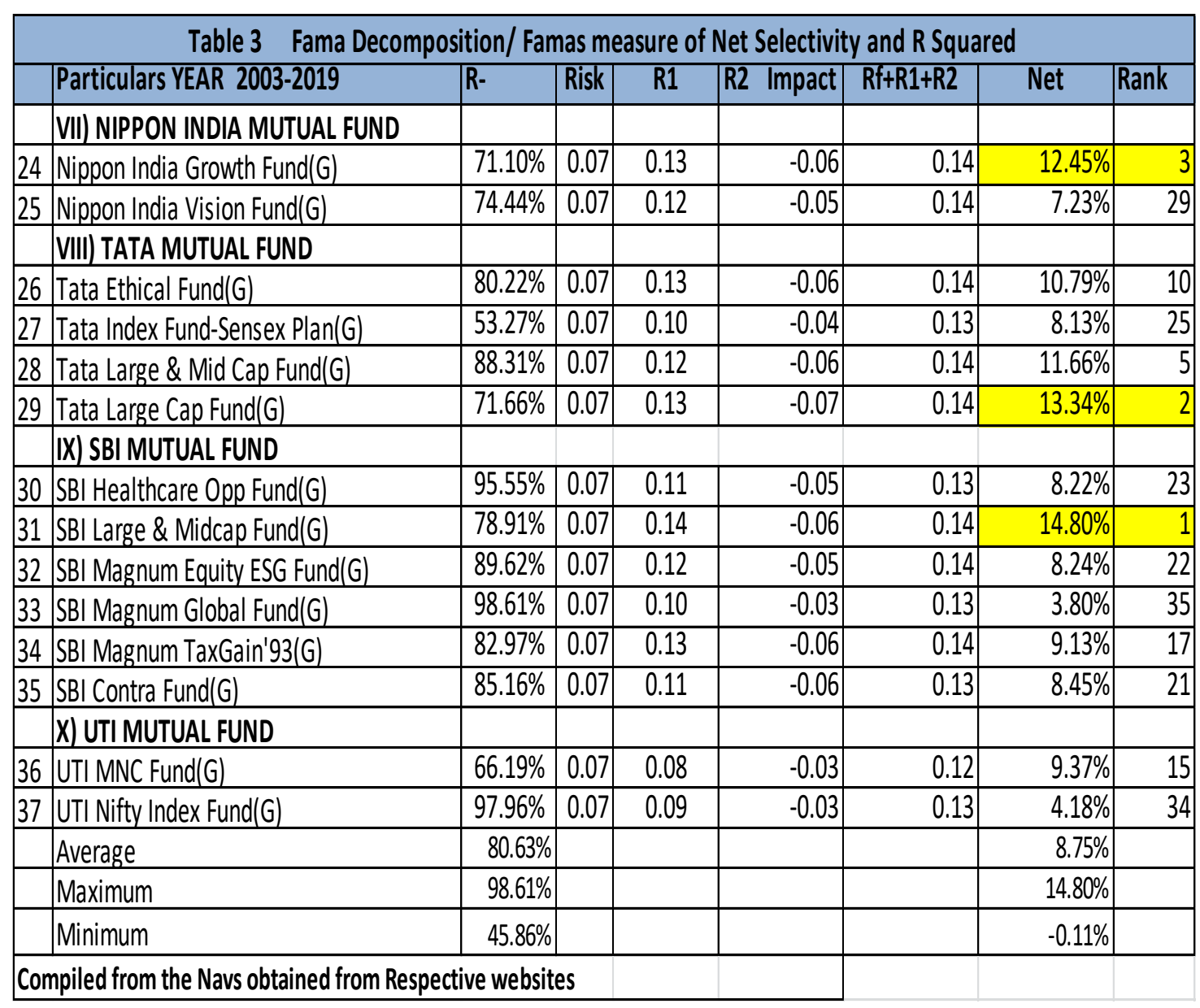

Out of 37 Schemes 4 Schemes namely Franklin India Technology Fund, ICICI Pru Saving Fund, Tata Index Fund and UTI MNC Fund have low $\mathrm{R}^{2}$ denoting less diversification and remaining Schemes have higher $\mathrm{R}^{2}$ denoting high diversification. This is to say that majority of the schemes covered in the study are well diversified

Famas Decomposition -distinguishes the performances of the portfolio fund on the basis of picking up the best securities at a specific risk from that of predictions of price movements in the market. According to Fama returns are based on selection of security, timing and risk bearing capacity. Fama has established Net Selectivity by dividing Fund performances into Four Components namely.

- Risk-free Return Rf

- Impact of Systematic Risk (R1): $\beta$ * (Rm-Rf)

- Impact of imperfect diversification (R2): $\left(\left(\sigma^{\mathrm{P}} / \sigma^{\mathrm{m}}\right)-\beta\right) *(\mathrm{Rm}-\mathrm{RF})$

- Net Superior Returns due to Selectivity: Rp- $\left(\mathrm{Rf}+\left(\left(\sigma^{\mathrm{P}} / \sigma^{\mathrm{m}}\right) *(\mathrm{Rm}-\mathrm{Rf})\right)\right)$ or $\mathrm{Rp}-$ $(\mathrm{Rf}+\mathrm{R} 1+\mathrm{R} 2)$.

The benefit which every Mutual Fund Unit holder has is portfolio diversification. Well diversified portfolios reduce the Portfolio risk, which is measured with $\mathrm{R}^{2}$. Net Selectivity is better measure for diversified Portfolios. A Positive Value for Fama indicated the Portfolios 
returns are higher than the returns which are expected and a negative Fama Value says that returns from portfolio are less than the expected return.

Fama's Net Selectivity Analysis: is analyzed through Returns against Risk, Diversification and Net Selectivity.

- Performance of Risk: An examination of Fama's Measure shows that all schemes have exhibited positive return in R1 i.e., against Systematic Risk Beta. SBI Large and Midcap Fund has the highest return of 0.14 .

- Performance of Diversification: This shows supplementary return available to Fund Manager due to diversifiability. All the Schemes in the table show negative return due to diversification denoting that not much is earned due to the Fund Managers ability in diversification.

- Performance of Net Selectivity: Net Selectivity is the variance of selectivity and diversification which accounts for Remaining Return. The table shows that except 1 Scheme i.e., ICICI Pru Saving Fund all the remaining schemes have Positive Returns. SBI Large and Midcap Fund earn the highest return due to Fama's Measure with $14.8 \%$ and Tata Large Cap Fund and Nippon India Growth Fund with 13.34\% and 12.45\% respectively.

\section{FINDINGS}

- It is found that out of the select Equity schemes all 37 schemes have earned positive return and SBI Large and Midcap Fund, Tata Large Cap and Nippon India Growth stand top three.

- Comparing Sharpe Returns of all the funds ICICI Pru FMCG Fund has the best performance and UTI MNC Fund and Aditya Birla Sunlife MNC Fund stand in $2^{\text {nd }}$ and $3^{\text {rd }}$ position.

- The fund that has the best performance as per Treyor is ICICI Pru FMCG Fund with UTI MNC Funds.

- ICICI Pru FMCG Fund has also proved to be the best in Jenson's Alpha with Nippon India Growth and SBI Large \& Midcap Fund ranking $2^{\text {nd }}$ and $3^{\text {rd }}$

- In Net Selectivity, ICICI Pru FMCG Fund has proved again the best by earning highest returns with Nippon India Growth and SBI Large \& Midcap Fund ranking $2^{\text {nd }}$ and $3^{\text {rd }}$

\section{CONCLUSION}

The study reveals that a majority of Schemes have performed better than their Benchmark Returns. In terms of Risk adjusted Performance, ICIC Pru FMCG Fund proved consistent in all the three measure of Performance i.e., Sharpe Ratio, Treynor ratio and Jenson's Alpha earning higher returns against Systematic Risk and Total Risk. It is concluded from the study that the higher return of the select schemes than the benchmark return is long standing performance rather than diversification. Fund managers skill is nowhere reflected in the study period in the diversification of the portfolios

\section{REFERENCES}

[1] Ajay Shah and Suban Thomas, "Performance evaluation of Portfolio Management in India", A Paper prepared by CMIE, 10 April, 1994.

[2] Venkatapathi Raju. D, "Mutual Funds in India: Investor's Perceptions", Quality Publishing Company. Bhopal, 2001. 
Performance of Equity Mutual Funds in India: An Analysis of Select Asset Management Companies

[3] Ajay Pratap Yadav(2014), "The Indian Mutual Fund Industry : From inception to Advancement”, Indian Journal Of Finance, Volume 9,Issue 5 (May 2015) ISSN 0973-8711, pp 47-61.

[4] Edwin J. Elton, Martin J. Gruber and Christopher R. Blake (1996) -“Survivorship Bias And Mutual Fund Performance", The Review of Financial Studies, Vol. 9, No. 4 (Winter, 1996), pp. 1097-1120.

[5] Jun Cai, K. C. Chan and Takeshi Yamada (1997)," The Performance of Japanese Mutual Funds", The Review of Financial Studies, Vol. 10, No. 2 (Summer, 1997), pp. 237-273.

[6] Musa Essayyad and H. K. Wu, (1988)" The Performance of U.S. International Mutual Funds", Quarterly Journal of Business and Economics, Vol. 27, No. 4 (autumn, 1988), Pp.32-46.

[7] F. Gokogoz(2010), "Measuring The Financial Efficiencies And Performances Of Turkish Funds “Acta Oeconomica, Vol. 60, No. 3 (September 2010), pp. 295-320.R.Nalini ((2013) "An Empirical study on the utility of Sharpe's Single Index Model in Optimal Portfolio construction", Indian Journal Of Finance, Volume 8, Issue 9 (May 2014) ISSN 0973-8711, pp 57-68.

[8] Dr R Narayanasamy \& V Rathnamani (2013) -"Performance Evaluation of Equity Mutual Funds" (On Selected Equity Large Cap Funds), International Journal of Business and Management Invention ISSN (Online): 2319 - 8028, ISSN (Print): 2319 - 801X www.ijbmi.org Volume 2 Issue $4 \|$ April. 2013\| PP.18-24.

[9] Honghui Chen, Hemang Desai and Srinivasan Krishnamurthy (2013),” A First Look at Mutual Funds That Use Short Sales", The Journal of Financial and Quantitative Analysis, Vol. 48, No. 3 (June 2013), pp.761-787.

[10] Omar Faruk Tan (2015)-“Mutual Fund Performance: Evidence from South Africa” Emerging Market Journal, Vol 5 No 2 (2015), ISSN2158-8707.

[11] Jun Huang and Albert Y. Wang (2015) "The Predictability of Managerial Heterogeneities in Mutual Funds", Financial Management, Vol. 44, No. 4 (WINTER 2015), pp. 947-979

[12] Venkata Naga Satya Surendra Chimakurthi, Digital Asset Management in the Communication of Product Promotional Activities, Asian Business Review, 10(3) 2020, pp.177-186

[13] Venkata Naga Satya Surendra Chimakurthi, The Challenges of New-Age Disaster Management, International Journal of Management (IJM), 11(4) 2020

[14] Inderjit Kaur (2019) - "Performance, Timing and selectivity skills of Indian equity Mutual fund : An Empirical Approach" Research World -Journal of Arts, Science \& Commerce,1E-ISSN 2229-4686,ISSN 2231-4172.

[15] www.amfiindia.com

[16] www.adityabirlasunlifemutualfunds

[17] www.dspmutualfunds

[18] www.franklinindiamutualfunds

[19] www.hdfcmutualfunds

[20] www.iciciprumutualfunds

[21] www.kotakmutualfunds

[22] www.nipponindiamuutalfunds

[23] www.tatamutualfunds

[24] www.sbimutualfund

[25] www.utimutualfund

[26] www.nse.india 
Annexure 1 ( as per AMFI)

Average Assets under Management (AAUM) for the quarter of January - March 2019 (Rs in Lakhs)

\begin{tabular}{|c|c|c|c|}
\hline $\mathrm{SrNo}=$ & Mutual Fund Name & Excluding Fund of Funds - & Rank \\
\hline 1 & HDFC Mutual Fund & 34229058.01 & 1 \\
\hline 2 & ICICI Prudential Mutual Fund & 32079287.15 & 2 \\
\hline 3 & SBI Mutual Fund & 28380667.27 & 3 \\
\hline & Aditya Birla Sun Life Mutual Fund & 24647965.44 & 4 \\
\hline 5 & \begin{tabular}{|l} 
Reliance Mutual Fund \\
\end{tabular} & 23361682.47 & 5 \\
\hline 6 & UTI Mutual Fund & 15969423.26 & 6 \\
\hline 7 & Kotak Mahindra Mutual Fund & 15009940.04 & 7 \\
\hline$\overline{8}$ & Franklin Templeton Mutual Fund & 11891223.26 & 8 \\
\hline$\overline{9}$ & \begin{tabular}{|l} 
Axis Mutual FundRank \\
\end{tabular} & 8972005.74 & 9 \\
\hline 10 & DSP Mutual Fund & 7836271.69 & 10 \\
\hline 11 & 1 L\&T Mutual Fund & 7094436.06 & 11 \\
\hline 12 & 2 IDFC Mutual Fund & 6935195.91 & 12 \\
\hline 13 & 3 Tata Mutual Fund & 5419359.24 & 13 \\
\hline 14 & Sundaram Mutual Fund & 3049727.07 & 14 \\
\hline 15 & Mirae Asset Mutual Fund & 2419129.42 & 15 \\
\hline 16 & 5 Invesco Mutual Fund & 2399038.53 & 16 \\
\hline 17 & 7 Motilal Oswal Mutual Fund & 1909043.04 & 17 \\
\hline 18 & LIC Mutual Fund & 1523991.86 & 18 \\
\hline 19 & Canara Robeco Mutual Fund & 1458341.67 & 19 \\
\hline 20 & Edelweiss Mutual Fund & 1166510.8 & 20 \\
\hline 21 & Baroda Mutual Fund & 1131968.94 & 21 \\
\hline 22 & HSBC Mutual Fund & 1105399.66 & 22 \\
\hline 23 & IDBI Mutual Fund & 926579.3 & 23 \\
\hline 24 & JM Financial Mutual Fund & 871238.54 & 24 \\
\hline 25 & PGIM India Mutual Fund & 762729.73 & 25 \\
\hline 26 & BNP Paribas Mutual Fund & 720920.03 & 26 \\
\hline 27 & 7|Principal Mutual Fund & 709070.32 & 27 \\
\hline 28 & 3 Indiabulls Mutual Fund & 480785.91 & 28 \\
\hline 29 & Mahindra Mutual Fund & 474810.62 & 29 \\
\hline 30 & Union Mutual Fund & 425910.06 & 30 \\
\hline 31 & 1 BOI AXA Mutual Fund & 362649.3 & 31 \\
\hline 32 & 2 YES Mutual Fund & 200012.41 & 32 \\
\hline 33 & 3 PPFAS Mutual Fund & 180520.25 & 33 \\
\hline 34 & 7 IIFL Mutual Fund & 164030.18 & 34 \\
\hline 35 & IL\&FS Mutual Fund (IDF) & 159286.13 & 35 \\
\hline 36 & Essel Mutual Fund & 141640.74 & 36 \\
\hline 37 & Quantum Mutual Fund & 136036.23 & 37 \\
\hline 38 & 3 IIFCL Mutual Fund (IDF) & 57998.35 & 38 \\
\hline 39 & Taurus Mutual Fund & 42421.11 & 39 \\
\hline 40 & quant Mutual Fund & 19619.73 & 40 \\
\hline 41 & 1 Shriram Mutual Fund & 12372.63 & 41 \\
\hline 42 & Sahara Mutual Fund & 5466.98 & 42 \\
\hline 43 & ITI Mutual Fund & 0 & 43 \\
\hline 44 & SREI Mutual Fund (IDF) & 0 & 43 \\
\hline & Grand Total & 244843765.1 & \\
\hline
\end{tabular}

